\title{
From Fictions and Aggregates to Real Entities in the Theory of the Firm
}

\author{
DAVID GINDIS*
}

University of Lyon 2, France

\begin{abstract}
According to the dominant 'nexus of contracts' and 'collection of assets' views of the firm, the firm is a either a fiction or an aggregate. Although legal personality is important in both accounts, everything is said to be achieved by private contract alone and the law's role in creating legal entity status is dismissed. The paper challenges both these aspects by reconsidering an alternative 'real entity theory' that dominated debates at the turn of the twentieth century. This forgotten view holds that the firm is neither a fiction nor an aggregate but a real entity, and underlines the creation of legal entity status as a fundamental role of the law. The paper discusses this view's ontological and legal insights, clarifies the proposition that the firm is a real entity, and proposes it as a starting point for a theory of the firm.
\end{abstract}

* Correspondence to: University of Lyon 2, Laboratoire d'économie de la firme et des institutions (LEFI), Institut des sciences de l'homme, 14 avenue Berthelot, 69007 Lyon, France. Email: david.gindis@univ-lyon2.fr

I am grateful to Bernard Baudry, Yuri Biondi, John Davis, Jan Dejnožka, Olivier Favereau, Francesca Gagliardi, Ivan Hernandez, Geoff Hodgson, Pavel Luksha, Eric Orts, Jean-Philippe Robé and the three referees of this journal for their valuable comments on previous versions of this paper. All remaining shortcomings are my own. 


\section{Introduction}

This paper argues that the two dominant economic perspectives on the firm, namely the 'nexus of contracts' (Jensen and Meckling, 1976) and the 'collection of assets' (Grossman and Hart, 1986) views, are variations on the same theme. These are 'fictionalist' and 'aggregationist' positions that rely on one of two moves: they either deny the existence of the firm by regarding it as a legal fiction and/or a shorthand form of expression, or they reduce the firm to an aggregate of its parts, be these contracts, individual owners of resources or nonhuman assets. In both cases, firms and similar social entities are said to be 'nothing but' aggregates of these parts. Furthermore, despite the fact that the legal personality is important in both accounts, everything is said to be achieved by private contract alone and the law's role in creating legal entity status is not considered. Dissatisfaction with these views has prompted a search for new foundations for the theory of the firm (Blair, 1999; Zingales, 2000).

Although rarely acknowledged by economists, both views are modern revivals of old theories of the corporation that have been recurring in a cyclical fashion for many centuries (Avi-Yonah, 2005). 'Fiction theory', which dominated Roman law and medieval debates, regards corporations as simply names or imaginary legal persons that are nothing more than the individuals composing them. 'Aggregate theory', popular in the second half of the nineteenth century, is a variant of fiction theory that holds that corporations are simply aggregates of natural persons, usually shareholders. However, examination of the legal literature reveals that an alternative 'real entity theory' dominated debates from roughly 1900 to 1930 . On this view, the 
corporation is neither a fiction nor an aggregate but a non-reducible real entity. Interestingly, Blair (1999) suggests that this forgotten view can provide new foundations for the theory of the firm. We follow this suggestion in this paper.

Three generations of entity theorists are distinguished in order to counter a common criticism that entity theory relies on dubious organicist and vitalist claims. Such claims, made by the early generation of entity theorists, were rejected by later entity theorists who provided other foundations for real entity theory. The paper identifies these useful insights and discusses the ontological issues involved in the ascription of reality to an entity such as the firm. There is clearly more to revisiting the entity theory of the past than the exploration of the history of a legal idea. Reviving real entity theory is particularly relevant in the context of the rising literature in economic and social ontology (Lawson, 1997; Weissman, 2000; Mäki, 2001; Davis, 2003; Hodgson, 2004). Indeed, the main dividing lines between both past and present theories are 'fiction vs. reality' and 'aggregate vs. entity', and Iwai (1999) appositely speaks of a dispute between 'corporate realists' and 'corporate nominalists'.

The debate structures discussions of both early corporate forms (monasteries, universities, charities, municipalities, guilds) and modern corporate forms (associations, trade unions, political parties, business corporations). The business corporation is traditionally distinguished from unincorporated business forms such as partnerships by its separate entity status. However, in the United States at least, the Revised Uniform Partnership Act of 1997 explicitly defines a partnership as 'an entity distinct from its partners’ (§201a). More generally, today’s new business 
entities combining aspects of both corporations and partnerships (limited liability companies, limited liability partnerships, limited limited liability partnerships) have made standard differences less obvious. Accordingly, discussions of legal entity status have shifted from corporations to most forms of business companies. Hansmann, Kraakman and Squire (2005: 13) thus hold that new business forms are 'generalizations' of the corporation, and Blackwell (1999) and others have called for a 'unified business entity code' applying to most if not all legal forms of the firm. ${ }^{1}$

These developments reinforce the relevance of real entity theory that applies to the firm in general and underlines the creation of legal entity status as an important role of the law. Although contemporary corporate theory is dominated by the nexus of contracts view (Bratton, 1989a) that holds that the law is limited to enforcing contracts and property rights, and should be where it is not, within this literature, the law's role in the creation of separate entity status is increasingly acknowledged (Hansmann and Kraakman, 2000). Iwai (1999) and Hodgson (2002) are among the few economists to have taken these issues seriously. It follows that reviving entity theory is also appropriate if one agrees that the "notion of the firm in economics ... has become dangerously devalued of legal meaning and ... institutional substance' (Hodgson, 2002: 37). The argument is developed in the four following sections. Section 2 examines the dominant theories of the firm. Section 3 reconsiders the

1 Although the term 'firm' is not a legal concept, all legally recognized business entities, including sole proprietorships, partnerships, corporations, cooperatives and the new business forms are species of the genus 'firm'. A theory of the firm is a theory of the common features of these species. Among these is the legal entity status attributed to each of these economic entities. Additional common features of firms as real entities are discussed in this paper. 
merits of real entity theory, underlining the genuine insights in its later versions. These aspects are assessed in section 4 that further advances an entity view of the firm. Section 5 concludes that the firm is a real entity that cannot be explained away or otherwise reduced.

\section{Fictions and Aggregates in the Theory of the Firm}

Since Coase's (1937: 393) statement of the nature of the firm as a contractual 'system of relationships', the contract, or the transaction as Williamson (1975) later emphasized, has become the basic unit of analysis in many branches of economic theory related to human interaction and organization. In this literature, the term 'contract' is broadly understood as any voluntary agreement involving some sort of exchange, including legally enforceable relations and both incomplete and implicit contracts. The essence of all forms of economic organization is said to be contractual (Alchian and Demsetz, 1972: 794; Jensen and Meckling, 1976: 310). This means that the firm is a voluntary coalition or team of individuals, and a set or collection of contracts between various owners of productive resources (Fama, 1980: 289; Alchian, 1984: 34; Alchian and Woodward, 1988: 66).

On this view, the difference between the firm and the market is a difference in degree and not a difference in kind. Not surprisingly, Jensen and Meckling (1976: 311) state that 'it makes little or no sense to try to distinguish those things that are "inside" the firm (or any other organization) from those things that are "outside" of it'. Since everything is contractual, 'the boundary of the firm is fuzzy: a bright line distinguishing "inside" and "outside" is missing" (Alchian and Woodward, 1988: 
76). It follows, as Barzel (1989: 54-55) argues, that the exercise of 'classifying transactions into those in the market and those within the firm ... is not very illuminating'. Insofar as they see the world as a 'contractual continuum', these theorists agree that the concept of firm boundaries is next to useless.

Frequently, the next step is to deny the usefulness of the concept of the firm itself. Many argue that definitions of the firm should be abandoned in favor of concepts of 'firm-likeness' (Demsetz, 1988: 155), 'firmness' (Lamoreaux, 1998: 70) or 'firmishness' (Klein and Coffee, 2002: 20) characterizing various sets of contractual relations. Alchian (1984: 46) writes: 'the "firm" loses some analytical significance as attention is focused on competition among individuals, their particular resources and on types of contractual relationships'. Cheung's (1983) classic paper on the contractual nature of the firm is equally explicit: 'what is or is not a firm is immaterial' (p. 10); in general, 'it is futile to press the issue of what is or is not a firm' (p. 18); better, 'we do not exactly know what the firm is - nor is it vital to know' (p. 3). The word 'firm' has 'little substantive content' (Jensen and Meckling, 1976: 311) and is 'simply a shorthand description of a way to organize activities under contractual arrangements' (Cheung, 1983: 3).

Although such statements suggest that economic analysis should look at individuals interacting as teams, given a distribution of opportunity costs and incentive compatibility constraints, these economists do provide a definition of the firm. The firm is defined as a 'nexus of contracts' (Jensen and Meckling, 1976: 310 311; Fama, 1980: 293; Fama and Jensen, 1983: 302; Demsetz, 1988: 154). This expression means that the firm is the only common signatory of a set of contracts. 
How can a non-defined, non-bounded thing which is simply a word be such a common signatory of a set of contracts? Surely this could only be done in imagination. Proponents of the nexus of contracts view provide a straightforward answer.

Jensen and Meckling (1976: 310) claim that firms are 'legal fictions', meaning that firms are legally treated as 'persons' signing the various contracts involved in the nexus. This is so only in imagination since real people do the actual signing in the name of the firm. Firms do not act, have objective functions or responsibilities. Only individuals can act, whether responsibly or not. Jensen and Meckling (1976: 311 , emphasis in original) warn us that 'the personalization (sic.) of the firm ... is seriously misleading. The firm is not an individual'. One should be wary of the 'reification illusion' (Klein and Coffee, 2002: 110) that leads to the common mistake of holding firms responsible for things that firms as such cannot commit. As Easterbrook and Fischel (1985: 89) explain, "the liability of "the corporation" is limited by the fact that the corporation is not real'. What holds for liabilities also holds for rights which "apply to individuals [and] not to imaginary "entities", (Hessen, 1979: 1328).

It is important to notice the difference between a 'set of contracts' and a 'nexus of contracts'. If individuals in a coalition contract with each other, it is easy to see that there are considerably more contracts that in a nexus in which parties do not contract with each other but do so with a central party, that is, the legal fiction of 
the corporate person. ${ }^{2}$ Since nexus of contracts theorists often use the two expressions interchangeably (e.g., Jensen and Meckling, 1976; Fama, 1980), it seems that when they speak of a nexus of contracts they are actually referring to a set of individuals and contracts. The latter are real, while the former is a fiction.

The nexus of contracts setup is a 'fictionalist' view of the firm involving an outright denial of the firm's existence based on three ontological claims. The first is that firms have vague boundaries or that firms are not determinate. The second is that firms are simply shorthand expressions as opposed to real entities. The third, that firms are legal fictions, is supposed to reinforce the claim that firms are ontological fictions. However, the links between the three claims are disputable. The step from vague boundaries to denial of existence is a non sequitur (Hodgson, 2002: 53; Dejnožka, 2006: 74ff). Similarly, the step from legal fiction to ontological fiction is also a non sequitur. Legal fictions need not be ontological fictions (Dejnožka, 2006: 4).

One interesting aspect of the 'collection of assets' view is that it was developed in reaction to the nexus of contracts view. Hart (1989: 1764) writes: 'the nexus of contracts approach does less to resolve the questions of what a firm is than to shift the terms of the debate'. For Hart, the nexus of contracts view is questionbegging, and its dismissal of firm boundaries is simply unreasonable. Moore (1992:

2 In a coalition of $n$ members (for any $n>3$ ), the number of possible contractual relations between all the members, $n(n-1) / 2$, is strictly greater than $n$, the number of individual contracts linking the $n$ members to a single central party. The role of this 'nexus' in the reduction of the necessary contracts and of the associated transaction costs is equivalent to the role played by Coase's 'entrepreneur'. 
494, n.2) sums up this position: 'One can ... sidestep the issue entirely, by arguing that everything is contractual, and that firms are a mirage ... This is the view proposed by Jensen and Meckling ... But if firms are a mirage, it is difficult to explain the enormous resources that firms expend merging and breaking up'.

Addressing this problem, Grossman and Hart (1986: 693) 'define the firm to consist of those assets that it owns or over which is has control'. The advantage of this definition is that one can ascertain firm boundaries in a straightforward manner. When looking for the firm in a contractual continuum world, the rule is simple: 'identify a firm with the assets it possesses' (Hart and Moore, 1990: 1120). Property rights thus provide a simple account of firm boundaries: assets that belong to the firm are 'inside' firm boundaries while assets that do not are 'outside'. Of course, this property rights view excludes human assets or human capital since these are inalienable, that is, they cannot be bought or sold.

This view of the firm seems very different from the nexus of contracts setup. Importantly, firms are said to be determinate. Nevertheless, the two views share much more in common than is usually acknowledged. For instance, in Hart and Moore's (1990) analysis, agents form coalitions depending on the expected value of their participation, which in turn depends on the effects of asset ownership. Contractual incompleteness renders ownership allocations relevant, since property rights condition incentives to invest in specific assets, thereby influencing the bargaining power of the parties involved. Alchian's (1984) account of specificity, specialization and coalitions is based on a similar story. 
More fundamentally, legal personality clearly plays an important role in both accounts, albeit an implicit one in the collection of assets setup. The nexus of contracts view implies that the fictitious central contracting party is the necessary link between the resource owners composing the coalition. The collection of assets view achieves the same result: since 'a firm is identified with the collection of physical assets over which the owner ... has residual control rights' (Moore, 1992: 496), the link is the concentration of property rights in the hands of one agent. The coalition of owners disappears and we are left with 'the owner' that personifies the aggregate of owners and becomes the sole central contracting party, much like the legal fiction of the corporate person. However, since both views focus on private contract alone, no further consideration is given to this legal feature of the firm.

What, then, is the link between the owner (e.g., employer) and the other agents necessary for production (e.g., employees)? The existence of such a link is important for a theory of the firm, and Hart (1995: 57) rightly stresses that 'without something to hold the firm together, the firm is just a phantom'. Hart (1995: 57-59) says:
A firm's nonhuman assets ... simply represent the glue that keeps the firm together ... If such assets do not exist, then it is not clear what keeps the firm together... One would expect firms without at least some significant nonhuman assets to be flimsy and unstable entities, constantly subject to the possibility of break-up or dissolution.

Clearly, Hart provides a wrong answer to a good question. Hart makes a logical mistake by stating that a collection holds itself together. Far from being the sort of thing that could bind anything together, a collection is itself in need of being bound 
together if it is to form a whole. Without some sort of 'glue', a collection is no different from a heap of sand easily blown away on a windy day. Arguably, Hart also makes a theoretical mistake by excluding human assets or people from his definition of the firm. Given that property rights hold nonhuman assets together, the glue question makes sense only if it is about what holds human beings together.

The collection of assets conception is an 'aggregationist' view of the firm, since the firm is said to be identical to its parts or 'nothing but' the collection of its parts. Debates on which parts are the firm's proper parts do not change this diagnosis. Hence the set of contracts view is equally aggregationist. Alchian (1984: 47, emphasis in original) says: 'it is not silly to consider the entry of a new stockholder to be the creation of a new firm'. Clearly, both approaches are variations on the same theme. The denial of the firm's real existence and the reduction of the firm to an aggregate of its parts, whatever these may be, arguably amount to the same thing. The former is simply more explicit than the latter. In both cases, the only real constituents of the world are said to be individuals, contracts and assets, and firms are said to be nothing but aggregates of these parts. We drive these points home in section 4 .

Interestingly, recent papers have called for new foundations for the theory of the firm. Expanding on Hart, Zingales (2000: 1649) argues that the firm is a 'nexus of specific investments' built over time and held together by strong complementarities between human and non-human capital. Blair (1999: 86) observes that the continuity and integrity of the firm may be enhanced by attributing key property rights to a separate legal entity. Accordingly, corporate law plays a greater 
role than is commonly acknowledged. Indeed, nexus of contracts theorists hold that corporate features such as separate entity status and limited liability can be achieved by private contract and market forces alone, and that the role of the law is limited to enforcing contracts and property rights (Hessen, 1979; Butler, 1989; Easterbrook and Fischel, 1991). On the contrary, the role played by the law in creating separate entity status for the firm needs to be recognized instead of being downplayed or ignored (Orts, 1998, 2007; Hansmann and Kraakman, 2000; Hodgson, 2002; Blair, 2003, 2004; Stout, 2005; Hansmann, Kraakman and Squire, 2005, 2006).

In this context, Blair (1999: 87) believes that we should 'reconsider the merits of an older school of legal scholarship that emphasizes that a corporation is a separate entity, and more than the sum of its parts'. Blair explicitly suggests that 'the entity view of the firm should be brought back to the center stage' (p. 59). Echoing this opinion, Orts (1998: 267) further suggests that 'a combination of legal and economic analysis opens the door for other disciplines besides economics to describe the social nature of the entities called firms'. The rest of this paper is devoted to these tasks.

\section{Real Entity Theory Reconsidered}

Discussion of the nature of the corporation has been often conflated with the issue of corporate personality, which itself has more often than not been related to the problem of the locus of legal rights and duties. These questions revolve around the legally fundamental distinction between subjects and objects, or persons and things (Iwai, 1999; Naffine, 2003). A 'legal entity' or 'legal person' is a legally recognized 
subject of rights and duties, capable of holding property, entering contracts, and so on. Not all human beings are legal persons (exceptions include infants and slaves) but all corporations are such persons. Debates on the 'right-and-duty-bearing unit' (Dewey, 1926: 565) must themselves be related to debates on the nature of legal rights. Savigny's (1841) 'will theory of rights' states that rights result from the right-holder's power of choice. However, Savigny's fiction theory clearly denies the reality of collective or corporate will. Regardless of volition, Jhering's (1852) 'interest theory of rights' sees rights as interests sufficiently important to be legally protected. Here, there is no logical need to decide whether corporations are real entities or merely fictions.

With these debates in mind, we now turn to the entity view that strongly influenced legal, social and political theory, as well as institutional economists such as Commons (1924), at the turn of the twentieth century. Some call this view the 'natural entity theory' (Millon, 1990; Horwitz, 1992) while others refer to it as the 'real entity theory' (Mark, 1987; Hager, 1989; Phillips, 1994). Sometimes both expressions are used interchangeably (Blumberg, 1990; Harris, 2006). For early entity theorists, the terms 'real' and 'natural' were equivalently used to oppose the then conflated terms 'fiction' and 'artificial'. Although all entity theorists regarded corporations and similar groups as real socio-economic entities, as opposed legal fictions existing only in contemplation of law, we identify three generations of entity theory based on important differences concerning the nature of the corporate entity and the issue of rights. It is unlikely that Blair refers to the first generation in her call for the revival of entity theory. 
The entity view is usually associated with Gierke's four-volume Das deutsche Genossenschaftsrecht. ${ }^{3}$ Maitland's famous translation of parts of Gierke (1900) disseminated his work in the Anglophone world. Gierke and many of his followers explicitly espoused Savigny's will theory of rights but rejected Savigny's fiction theory. In his translator's introduction, Maitland (Gierke, 1900: xxvi) writes of the corporation that it

is no fiction, no symbol ... no collective name for individuals, but a living organism and a real person, with body and members and a will of its own. Itself can will, itself can act ... It is not a fictitious person ... It is a group-person, and its will is a group-will.

Gierke's and Maitland's organicist and vitalist position holds that corporations are real beings with real volition. Against Savigny, statements such as 'the personality of the corporation ... is in no sense ... artificial or fictitious, but is every whit as real and natural as is the personality of man' (Maitland, 1900: 335-336) explicitly seek to establish that the corporation can be an 'ultimate moral unit' (Maitland, 1905: 199), that is, a natural subject of rights.

A second generation of entity theorists argued that there is no supra-individual geist: the 'corporate entity is not a rational being [and it] has no will' (Machen, 1911: 265). For Machen, fiction theory contains a grain of truth, namely that the

3 Translated as 'The German Law of Fellowship'. The three relevant volumes were published between 1868 and 1881. The entity view can be traced back to Gierke's mentor, Beseler, who first introduced the term genossenschaft ('fellowship') in 1843 (Harris, 2006: 1428). Within the German Historical School of Law, Beseler and Gierke were leading Germanist figures who opposed the Romanist followers of Savigny in the context of the drafting of the German Civil Code. 
proposition that 'a corporation is a person' is either a metaphor or a legal fiction. However, Machen continues, 'although corporation personality is a fiction, the entity which is personified is no fiction' (p. 266). Machen (1911:258) is careful to distinguish between two questions conflated by the earlier generation:

There are two basic propositions, (1) that a corporation is an entity distinct from the sum of the members that compose it, and (2) that this entity is a person. These propositions are often confused; but they are properly quite distinct from one another ... One who denies that a corporation is really a person ... is not bound by logical consistency to deny the reality of the corporation as an entity distinct from the sum of the members.

Machen rightly stresses that the ontological question contained in the first proposition needs to be addressed separately. Several insights can be found in the writings of the second generation.

According to Dicey (1905: 154), 'whenever men act in concert for a common purpose, they tend to create a body which, from no fiction of law, but from the very nature of things, differs from the individuals of whom it is constituted'. Given this concerted action and common purpose, Brown (1905: 369) argues, 'the group becomes, or tends to become, a unit ... A mere sum of individuals as such can no more become a unit than a heap of sand can become a statue'. In this spirit, one of the clearest statements made by entity theorists is Freund's (1897: 47) list of three 'salient characteristics of the body corporate: its unity, its distinctiveness and its identity in succession'. 
For Freund, if these features are in fact present in a given association, then one can speak of a real entity. The difficulty is to show how common purpose and collective action produce a level of unity, distinctiveness and durability sufficient for the group to be a real entity without appealing to any literally volitional or moral features. ${ }^{4}$ It is important to notice that Freund, Dicey and Brown clearly associate existence, identity and unity of groups in general. Indeed, 'the inquiry is one which leads us on from the subject of corporations to the wider subject of human association in general' (Brown, 1905: 368).

Entity theorists repeatedly underlined the role played by the law, claiming that the law should comply with the fact of the group's socio-economic existence and attribute legal capacity to an already existing or a potential socio-economic capacity. Accordingly, Laski (1916: 422) argues that 'the entities the law must recognize are those which act as such, for to act in unified fashion is - formality apart - to act as a corporation'. Legal entity status attributed by the law unifies and reinforces the socio-economic capacity created by concerted action and common purpose. It thus greatly increases the possibilities of collective action. Many entity theorists were political pluralists who believed in freedom of association, and the increasing legal recognition of various groups (associations, trade unions, political parties) sat well with their theory.

Of course, nothing precludes the law from considering that a given group is a legal entity even if it is not really a unified group. Political or tax considerations

4 Freund studied in Germany where he encountered Gierke's theory before Maitland's translation. Regardless of chronology, Freund is clearly what we have called a second generation entity theorist. 
may enter the picture and in fact often do (Dewey, 1926; Hager, 1989; Avi-Yonah 2005). Second-generation entity theorists readily admitted this possibility. Vinogradoff (1924: 604) writes: 'the life of groups has two sides, i.e., the social contents which are real and produce the union, and the legal form which has to be arranged artificially by the State in order to safeguard public and private interests'. Contrary to the earlier generation, second generation entity theorists adopt Jhering's interest theory of rights. Hence, 'the essence of juristic personality does not lie in the possession of rights but in subjection to liabilities' (Machen, 1911: 263).

Entity views encountered increasing resistance. Typical attacks include Singleton's (1912: 291) position that 'nothing is to be gained from the spinning out of ontological theories incapable of verification'. Wormser (1912: 496) likewise sees a 'tempting but profitless discussion'. In this context, an important blow was delivered by Dewey's (1926) influential instrumentalist discussion. Courts, Dewey argues, should avoid the legally profitless debate regarding essential definitions of the corporate entity. When facing actual decisions, courts should consider only the practical consequences involved and avoid reference to some abstract general theory. From the same point of view, many legal realists regarded entity theory as 'a matter of literature' (Radin, 1932: 667) and dismissed it as 'transcendental nonsense' (Cohen, 1935). With the rise of both instrumentalism and legal realism in the late 1920s and 1930s, by the time of Berle and Means (1932), papers upholding entity views became very rare.

One exception is Rowley's (1931: 558) suggestion that talk of personality should be abandoned in favor of a better term, 'individuality'. Recall that Jensen and 
Meckling (1976) conflate the two terms. As we have seen, personality is a legal term involving rights and duties. Wrongly suggesting that some moral issue is involved or that personality is the mark of responsible human beings only, the term is the source of much confusion (Gindis, 2007: 275). Individuality, on the other hand, refers to distinctive existence or individuation and unity (and sometimes to indivisibility), and Rowley (1931: 560) rightly states that 'anything has this individuality, otherwise it is not a thing'. Another exception is Dodd's (1932: 1160) view that 'any organized group, particularly if its organization is of a permanent character, is a factual unit', and that in general, 'if the unity of the corporate body is real, then there is reality'.

Berle (1947: 344) later agreed that 'the entity commonly known as "corporate entity" takes its being from the reality of the underlying enterprise, formed or in formation'. Arguing that it is 'the enterprise, and not the incorporation papers, [that] is the true entity' (p. 358), Berle applies his theory of enterprise entity to de facto corporations and to corporate groups, that is, to cases where economic entity and legal entity do not match. Following Berle's lead, Dix (1953) further extends the entity view to corporate mergers and groups. A final entity view worth mentioning is Stauss's (1944: 112, emphasis in original) subtle position according to which the firm is both independent from and dependent on its members:

The entity known ... as the firm is taken as a real institution. As such, the firm exists apart from the individuals who compose its decisionmaking organization, but it does not function apart from them. Thus the entity is not a fiction; it is a fact. 
Rowley, Dodd, Berle, Dix and Stauss are the third generation of entity theorists since the accent is neither on the defense of group-will views (first generation) nor on denials of group-will views and attempts to provide other foundations for entity theory (second generation). Contrary to the first two generations who had concentrated on essential definitions, the third generation abandoned talk of personality and concentrated on consequences of the entity view.

Critics have all too often reduced entity theory to the first generation (e.g., Bratton, 1989b: 1512) and have argued that since entity theorists admit all sorts of geists and vital forces, their theory is to be discarded. But it is important to understand that these more dubious aspects were abandoned by later entity theorists themselves. Another important observation that commentators rarely mention is that Dewey's attack was confined to essentialist thinking in the realm of judicial decision only. Contrary to the standard account (e.g., Bratton, 1989b: 1491), Dewey's (1926: 673) comments on Dicey do not dispute the reality of the unified body created by people acting together for some common purpose. However, like Machen, he simply does not think that issues of reality and legal personality should be conflated. Dewey is closer to later entity theorists than is commonly acknowledged. Dewey (1925: 163) writes:

A corporation is neither a mental state nor a particular physical event in space and time ... It is an objective reality which has multitudinous physical and mental consequences. It is something to be studied as we study electrons; it exhibits as does the latter unexpected properties ... It would not exist ... apart from the interaction of human beings with one another. 
Dewey believes that the corporation is neither a conceptual entity nor a physical entity. In modern language, one would say that it is an 'institutional kind' (Thomasson, 2003), that is, an object of social ontology and not of natural science. Dewey also believes that corporations exhibit new properties that do not exist in the absence of specific human interactions. Corporations, just like other complex systems, possess emergent properties that have consequences. Freund (1897) makes a similar point, and Brown (1905: 379) argues that individuals, as members of groups, are affected by their membership: 'qualities have been developed in [them] which cannot be explained save by reference to the union'.

Overall, second and third generation entity theorists held that the firm is more than the aggregate of its parts and different from a heap. Existence, identity, unity and persistence are associated. Unity is produced by common purpose, concerted action and organization. There is also an important sense in which the firm is both independent from and dependent on its members. This can be best understood as a problem of emergent properties. Put together, these ontological insights clearly state that the firm is real or at least as real as its members. These, then, are the relevant aspects of entity theory that need to be brought back to the center stage if one seeks to build a theory of the firm in which the firm is neither a fiction nor an aggregate.

\section{Advancing a Real Entity View of the Firm}

Fictionalism and aggregationism in both economic theory and legal doctrine are varieties of ontological individualism, the view that reality is ultimately composed of individuals only (although contracts and assets may be included), and that firms 
and similar social entities are 'nothing but' the individuals composing them, or 'nothing over and above' these individuals. On the contrary, the argument here is that a case can be made for the fact that the firm is a real entity and that ontological individualism is untenable, as is the systematic reduction of the firm to any of its parts. However, further clarification of the notion of 'real entity' is needed. We argue our case by advancing several interrelated requirements that a thing needs to satisfy in order for it to be considered a real entity. This approach is similar in spirit to Davis's (2003) examination of conditions of individuality. Davis (2003: 185) says:

\footnotetext{
If we want to know whether an object term in a theory picks out a real thing in the world, we characterize that object as being of a certain kind, ask what existence tests that sort of thing as described must satisfy for it to be said to exist, and finally check whether the conception in question satisfies the appropriate tests.
}

This is how we shall proceed in the following. Relevant 'existence tests' for a real entity view of the firm include identity, unity and persistence. The possession of some form of causal power is also important. These features exclude aggregates from the category of real entities.

Real entities, in the language of traditional philosophy, are different from mere concepts, shorthand expressions or fictitious entities. Traditionally, an entity is said to be real if it exists or can exist independently of our knowledge or language. There are different ways to define independence and these depend on the entity in question. Natural kinds such as rocks and trees are completely independent. 
Arguably, the entities composing the social realm - institutional kinds such as firms - depend at least in part on us for both their creation and persistence. However, although institutional kinds do not meet the strong realist requirement of entities entirely independent of us for their existence, 'they certainly are ... not mere mental constructs' (Thomasson, 2003: 605). These differences notwithstanding, a general way to define a real entity is to say that real entities can exist apart from each other.

Importantly, for any thing to be an entity, it must be identifiable, that is, it must satisfy some identity criteria. We take Quine's (1969: 23) dictum, 'no entity without identity', to be a necessary condition meaning that a candidate entity can be individuated or distinctly identified relatively to other things according to some key characteristics. Rowley (1931) makes the same point. Like Davis (2003: 12-13), we also take identity through time to be important since persistent entities can be reidentified over time and through change according to the same key defining respects. Lowe (2003: 335, emphasis in original) points out that this implies unity: 'an individual object is an entity which, quite literally, counts as one entity of some kind, in order to do which it must possess unity'. Indeed, Quine's dictum, as Dejnožka (2003: 184-185) explains, has roots in the past and in particular in the philosophy of Leibniz (1902 [1687]: 191, emphasis in original) according to which 'what is not truly $a$ being is not truly a being'.

This leads Leibniz to exclude aggregates from the category of real entities: 'where there are only beings by aggregation, there are not even real beings' (p. 189), since 'beings by aggregation ... have their unity only in our minds' (p. 191). Similar arguments can be found in Plato (Sophist 245) and Aristotle (Metaphysics Z, 17, 
1041b) who uses the term 'heap'. Clearly, any candidate entity should have the real unity that aggregates and heaps lack. An important case in point is that of an entity having not only certain characteristic kinds of parts, but also a characteristic constitutive structure. Baker (2004: 101) appropriately says that 'constitution is a relationship of unity' explaining the non-identity between the whole and any aggregate of its parts. Baker (ibid.) further claims that 'constitution is a relation that accounts for the appearance of genuinely new kinds of things with new kinds of causal powers'.

Recall that Plato's Eleatic Stranger (Sophist 247e) famously argued that a sufficient mark of real things is the power to affect other things and to be affected by them. Causal powers, dispositions or capabilities are significant features of any real entity. ${ }^{5}$ Therefore, this is a crucial existence test for entities such as firms.

Discussion of this requirement often appeals to two types of arguments: an argument from emergence and an argument from constitutive rules. Both can be found in the writings of second generation entity theorists. Both seek to distinguish identifiable and persistent 'social integrates' (Pettit, 2002) from mere aggregates of individuals. Both support the view that wholes arising from a constitution relation are qualitatively different from their parts taken separately or collectively, and that it is no longer possible to hold that these wholes are 'nothing but' the parts composing them, or 'nothing over and above' these parts.

5 Similar statements on the causal ascription of reality have been made by Harré and Madden (1975: 86ff), Lawson (1997: 31), Mäki (2001: 370ff), Molnar (2003: 208ff), Hodgson (2004: 406), Elder-Vass (2005: 331ff), Dejnožka (2006: 24), Bunge (2006: 239ff) and many others. 
The argument from emergence is that emergence is the 'failure of aggregativity' (Wimsatt, 1997: S372). In other words, resultant properties, or macroproperties of sums and aggregates, are to be distinguished from truly emergent properties that entail 'qualitative novelty' (Bunge, 2003: 14). New properties at the emergent level, not to be found among its constituents however considered, are generated by the 'causal reciprocity' of proper parts interacting in a constitutive structure (Weissman, 2000: 47). This can help explain collective knowledge and capabilities that are neither reducible nor ontologically equivalent to individual knowledge and capabilities. Importantly, emergents are 'integrated wholes that tend to maintain some sense of identity over time' (Goldstein, 1999: 50) and 'survive the demise of particular individuals that once related to them' (Hodgs on, 2004: 12). However, the most important but most controversial aspect of emergents is their possession of some form of causal power.

One recent formulation is the notion of 'reconstitutive downward causation' (Hodgson, 2003: 164-165; Hodgson, 2004: 184ff). On this view, also held by Brown (1905), emergent entities causally change, even if the change is very slight, those things from which they have emerged. Things that are parts of wholes are different from what they are in the absence of the constitutive relations that account for emergence. This means that parts cannot be taken as given. Individual knowledge and capabilities, for instance, are affected by collective knowledge and capabilities. Furthermore, if the emergent entity can causally affect those things from which it emerges, then it is both independent from and dependent on those things. ${ }^{6}$ These 
ideas are particularly relevant for the analysis of social entities such as firms from the 'structure and agency' perspective (Lawson, 1997; Hodgson, 2004) that usefully links the argument from emergence and the argument from constitutive rules.

The argument from constitutive rules further underlines the constitutive structure that distinguishes aggregates such as crowds from institutional kinds such as firms (French, 1982; Copp, 1979, 1984). Broadly understood, the argument is that 'constitution is the essential basis of an organization, the link that ties its members together' (Vanberg, 1992: 243). Vanberg (p. 240) argues that 'the procedural rules that underlie organized or corporate action ... constitute organizations as corporate actors'. Freund (1897) similarly explains corporate agency without appealing to group-wills. The argument is summed up by Searle's (2005: 10) constitutive rule: 'X counts as $\mathrm{Y}$ in context $\mathrm{C}$ ' creates new 'deontic powers', that is, rights, duties, obligations and empowerments. Interestingly, Searle claims that private recognition of these powers is insufficient: 'there has to be official recognition by some agency ... and there have to be status indicators issued by the official agency' (p. 15). The law's creation of legal entity status is thus a fundamental institutional fact about the firm.

Fictionalists argue that firms cannot exist without any individuals. We do not dispute this. Yet the firm's both economic and legal persistence through time, based emergent. Kim (2006: 557) appeals to Occam's razor to cast doubt on the causal efficacy of the emergent, arguing that supervenience can account for any supposed case of downward causation. Humphreys (1997: S338-S339) defends emergence, arguing that supervenience contains nothing in it to make it a necessary vertical relation. Even if applied to a vertical relation between levels, supervenience retains the ontological priority of the lower level: once the facts about the lower entities are set, so too are all the higher level facts. This is a qualified form of reductionism. 
on its constitutive structure that allows the replication of behavioral patterns and collective routines, implies that any particular firm continues to exist even if all its present human members are progressively replaced. Such independence qualifies the firm as a real entity. This fits an important insight from the evolutionary theory of the firm, namely that collective knowledge and capabilities are typically 'sticky', that is, retained through progressive change in firm membership (Nelson and Winter, 1982: 99ff; Winter, 1988: 172). ${ }^{7}$ If this were not the case, the firm would certainly be a flimsy entity, incapable of survival in an evolutionary setting. Significantly, the firm can only be a 'unit of selection' if it is cohesive and durable, that is, if its members 'are bound together in a sufficiently cohesive manner to share a mostly common fate' (Hodgson and Knudsen, 2004: 300). Unitary legal status is important in this respect.

Legal entity status also matters for the boundaries of the firm. Firms are 'indivisible' legal persons that appear in court as single parties (Iacobucci and Triantis, 2007: 524). Divisions within the firm, on the other hand, cannot sue or be sued, cannot own property, and cannot contract (unless exercising delegated powers) since they do not have legal personality. Since internal transfers do not generally involve the exchange of legal property rights, as Hodgson (2002: 46) similarly explains, there are no markets within the firm. Given the accent on legal indivisibility, the boundaries of the firm are to be drawn such that there are two

7 Similar considerations can be found in the capabilities view of the firm developed in the tradition of Penrose (1959: 22ff). In line with real entity theory, firms are seen as cohesive wholes identifiable by their distinctive and persistent capabilities. 
firms whenever there are legal contracts between two legal persons. Employees and managers act as agents of the firm during their contractual time of employment or according to any other contractual stipulation. As such, their legal identity is different from the legal persons they are when acting as consumers outside working hours, that is, 'outside' the firm. The fact that boundaries may sometimes be difficult to draw does not mean that there are no firms.

Matters seem less straightforward in cases where an economic entity is formally organized as a multiple legal entity structure. Traditional corporate law sees corporate groups, for instance, as aggregates of legal entities instead of singular economic entities. Multinational enterprises likewise exist as separate legal entities in different countries. In this context, like third generation entity theorists, Blumberg (1993) argues that courts should not systematically place 'form over substance' or 'legal entity over real enterprise', especially in terms of group liabilities. Blumberg (1993: 89ff) documents numerous court decisions based on 'enterprise principles' that acknowledge the reality of a singular economic entity based on various existence tests emphasizing, among other things, unity of control. Of course, whether corporate groups are 'considered one entity or a group of entities will depend ... on the question at hand' (Orts, 1998: 313). Arguably, a real entity view provides a useful framework for addressing such issues. ${ }^{8}$

8 Although corporate groups, multinational enterprises, conglomerates and the like allow internal transfers of property rights, it is highly misleading to speak of 'intra-firm markets'. It is important of develop additional concepts such as 'non-market exchange' to account for these different economic and legal structures (Hodgson, 2002: 45, 47). 
Unlike aggregates, sets, collections and heaps, the firm is held together by 'ontological glue' (Gindis, 2007: 279). This includes: ‘institutional glue' created by legal entity status, constitutive rules, contracts and norms; 'organizational glue' manifested by structures, processes, functions and roles; 'motivational glue' that ensures loyalty and adherence to common goals through a variety of means; 'cognitive glue' accounting for identification, shared beliefs and representations; and 'capabilities glue' that relates to the complementarity between human assets such as knowledge and non-human assets, to productive routines, and so on. Firm heterogeneity is partly explained by the existence of indefinitely many blends and combinations of these types of glue. Overall, glue contributes to the firm's cohesion and unifies the collective action of its members through time, thus contributing to the firm's causal powers vis-à-vis the rest of the world. Although these considerations abstract away from internal conflict, we do not wish to imply that internal conflict is absent or should be ignored, but only that the firm's unity is generally sufficient to prevent dissolution.

\section{Conclusion}

Masten (1988: 184) believes that the question of the nature of the firm is about 'whether the firm represents a distinct institution'. Khalil (1997: 519) agrees that 'whether the firm is an individual is the central question'. As we have seen, second and third generation entity theorists are of the same opinion. Our accent on existence, identity, unity and persistence in the preceding section also reinforces the importance of the individuality or singularity of the firm. Accounting is similarly based on the distinct entity principle (Biondi, 2007: 248). This makes sense, since 
firms as identifiable structured wholes compete with other firms as identifiable structured wholes. Firms as singular wholes can produce and be competitive or not. Firms as wholes possess capabilities and undertake risk-bearing activities. Firms as wholes have temporal reputations in transactions and generate income or suffer losses. Firms as wholes can sue and be sued (although courts sometimes 'pierce the corporate veil'). Firms as wholes are subject to hostile takeover bids.

There is nothing imaginary about these institutional and economic facts. Arguably, the firm's identity, unity and persistence allow us to properly speak of collective capabilities, firm competitiveness, reputation, and so on, as emergent properties and causal powers of the firm. Sets of contracts and collections of assets simply do not have any of these properties and causal powers. Clearly, neither do fictions and aggregates. It follows that any explanation of the above facts cannot not assume that the firm is a real entity. We thus conclude that firms are real entities by inference to the best explanation. Accordingly, the firm cannot be denied, explained away or otherwise reduced. This is not only a reasonable starting point for a theory of the firm. It also needs to be assumed in order for there to be markets and competition.

Just as individuals and assets are among the proper parts of firms, firms are among the proper parts of markets. Conversely, on a strictly logical basis, firms do not have markets as their parts. Therefore, a crucial consequence of our discussion is that the difference between the firm and the market is a difference in kind and not in degree. Market transactions are events and relations between firms and other economic entities, as Simon's (1991: 27) visitor from Mars would concur. Markets, 
however, are not reducible to market transactions since they are organized systems of property rights exchange (Hodgson, 2002: 44). Importantly, the legal structure that is essential for markets relies on the institutional fact that firms are singular legal entities that can hold property and act in certain market-like ways (e.g., engage in market transactions, compete, merge) such that some even thrive.

This observation, rarely discussed by economists, is gaining attention within legal scholarship that increasingly recognizes that legal entity status protects corporate assets by 'locking-in capital' (Blair, 2003, 2004; Stout, 2005). The exclusive focus on 'owner shielding', that is, on the protection of a firm's owners from the claims of the firm's creditors, has obscured the economic and historical importance of 'entity shielding', that is, the protection of a firm's assets from the personal creditors of its owners (Hansmann, Kraakman and Squire, 2005, 2006). This is the most vital legal feature of the firm that could not have been sustained by private contract alone. Although there is considerable debate regarding this point (e.g., Mahoney, 2000; Ribstein, 2006), it is reasonable to assume that transaction costs are greatly reduced by legislative provision of entity status. Without this feature that allows firms to own and pledge assets, reducing the costs of credit and protecting the going concern value, it is difficult to understand not only the nature of the firm but also the rise of the firm in history. This means that law and legal recognition play important roles in economic development. 


\section{References}

Alchian, Armen A. (1984), 'Specificity, Specialization and Coalitions', Journal of Institutional and Theoretical Economics, 140(1): 34-49.

Alchian, Armen A. and Harold Demsetz (1972), 'Production, Information Costs and Economic Organization', American Economic Review, 62(5): 777-795.

Alchian, Armen A. and Susan Woodward (1988), 'The Firm Is Dead; Long Live the Firm: A Review of Oliver E. Williamson's The Economic Institutions of Capitalism', Journal of Economic Literature, 26(1): 65-79.

Aristotle, Metaphysics, in Richard McKeon (2001) (ed.), The Basic Works of Aristotle, New York: Modern Library.

Avi-Yonah, Reuven S. (2005), 'The Cyclical Transformations of the Corporate Form: A Historical Perspective on Corporate Social Responsibility', Delaware Journal of Corporate Law, 30(3): 767-818.

Baker, Lynne R. (2004), 'The Ontology of Artifacts', Philosophical Explorations, 7(2): 99111.

Barzel, Yoram (1989), Economic Analysis of Property Rights, Cambridge: Cambridge University Press.

Berle, Adolf A. (1947), ‘The Theory of Enterprise Entity', Columbia Law Review, 47(3): 343-358.

Berle, Adolf A. and Gardiner C. Means (1932), The Modern Corporation and Private Property, New York: Harcourt, Brace \& World.

Biondi, Yuri (2007), 'Accounting and the Economic Nature of the Firm as an Entity', in Yuri Biondi, Arnaldo Canziani and Thierry Kirat (eds), The Firm as an Entity: Implications for Economics, Accounting and the Law, London and New York: Routledge.

Blackwell, Thomas F. (1999), 'The Revolution is Here: The Promise of a Unified Business Entity Code', Journal of Corporation Law, 24(2): 333-378.

Blair, Margaret M. (1999), 'Firm-Specific Human Capital and Theories of the Firm', in Margaret M. Blair and Mark J. Roe (eds), Employees and Corporate Governance, Washington, DC: Brookings Institution Press. 
Blair, Margaret M. (2003), 'Locking-In Capital: What Corporate Law Achieved for Business Organizers in the Nineteenth Century', UCLA Law Review, 51(2): 387-455.

Blair, Margaret M. (2004), 'The Neglected Benefits of the Corporate Form: Entity Status and the Separation of Asset Ownership from Control', in Anna Grandori (ed.), Corporate Governance and Firm Organization: Microfoundations and Structural Forms, New York: Oxford University Press.

Blumberg, Phillip I. (1990), 'The Corporate Personality in American Law: A Summary Review', American Journal of Comparative Law, 38(S): 49-69.

Blumberg, Phillip I. (1993), The Multinational Challenge to Corporation Law: The Search for a New Corporate Personality, New York: Oxford University Press.

Bratton, William W. (1989a), 'The "Nexus-of-Contracts" Corporation: A Critical Appraisal', Cornell Law Review, 74(2): 407-465.

Bratton, William W. (1989b), 'The New Economic Theory of the Firm: Critical Perspectives from History', Stanford Law Review, 41(6): 1471-1527.

Brown, William J. (1905), 'The Personality of the Corporation and the State', Law Quarterly Review, 21(4): 365-379.

Bunge, Mario (2003), Emergence and Convergence: Qualitative Novelty and the Unity of Knowledge, Toronto: Toronto University Press.

Bunge, Mario (2006), Chasing Reality: Strife over Realism, Toronto: Toronto University Press.

Butler, Henry N. (1989), 'The Contractual Theory of the Corporation', George Mason University Law Review, 11(4): 99-123.

Cheung, Steven N.S. (1983), 'The Contractual Nature of the Firm', Journal of Law and Economics, 26(1): 1-21.

Coase, Ronald H. (1937), 'The Nature of the Firm', Economica, 4(16): 386-405.

Cohen, Felix S. (1935), 'Transcendental Nonsense and the Functional Approach', Columbia Law Review, 35(6): 809-849.

Commons, John R. (1924), Legal Foundations of Capitalism, New York: Macmillan.

Copp, David (1979), ‘Collective Actions and Secondary Actions', American Philosophical Quarterly, 24(4): 177-186. 
Copp, David (1984), 'What Collectives Are: Agency, Individualism and Legal Theory', Dialogue, 23(2): 249-269.

Davis, John B. (2003), The Theory of the Individual in Economics: Identity and Value, London and New York: Routledge.

Dejnožka, Jan (2003), The Ontology of the Analytic Tradition and Its Origins: Realism and Identity in Frege, Russell, Wittgenstein and Quine, $2^{\text {nd }}$ edition, New York: Rowman $\&$ Littlefield.

Dejnožka, Jan (2006), Corporate Entity, unpublished book manuscript (available online at http://www.members.tripod.com/ Jan_Dejnozka/corporate_entity_book.pdf).

Demsetz, Harold (1988), 'The Theory of the Firm Revisited', Journal of Law, Economics and Organization, 4(1): 141-161.

Dewey, John (1925), Experience and Nature, Chicago: Open Court.

Dewey, John (1926), 'The Historic Background of Corporate Legal Personality', Yale Law Journal, 35(6): 655-673.

Dicey, Albert V. (1905), Lectures on the Relation between Law and Public Opinion in England during the Nineteenth Century, London: Macmillan.

Dix, Maurice J. (1953), ‘The Economic Entity’, Fordham Law Review, 22(3): 254-273.

Dodd, E. Merrick (1932), 'For Whom Are Corporate Managers Trustees?', Harvard Law Review, 45(7): 1145-1163.

Easterbrook, Frank H. and Daniel R. Fischel (1985), 'Limited Liability and the Corporation', University of Chicago Law Review, 52(1): 89-117.

Easterbrook, Frank H. and Daniel R. Fischel (1991), The Economic Structure of Corporate Law, Cambridge, MA: Cambridge University Press.

Elder-Vass, Dave (2005), 'Emergence and the Realist Account of Cause', Journal of Critical Realism, 4(2): 315-338.

Fama, Eugene F. (1980), 'Agency Problems and the Theory of the Firm', Journal of Political Economy, 88(2): 288-307.

Fama, Eugene F. and Michael C. Jensen (1983), ‘Separation of Ownership and Control', Journal of Law and Economics, 26(2): 301-325. 
French, Peter A. (1982), 'Crowds and Corporations', American Philosophical Quarterly, 19(3): 271-277.

Freund, Ernst (1897), The Legal Nature of Corporations, Chicago: Chicago University Press.

Gierke, Otto von (1900), Political Theories of the Middle Age, translated with an introduction by Frederick W. Maitland, Cambridge: Cambridge University Press.

Gindis, David (2007), 'Some Building Blocks for a Theory of the Firm as a Real Entity', in Yuri Biondi, Arnaldo Canziani and Thierry Kirat (eds), The Firm as an Entity: Implications for Economics, Accounting and the Law, London and New York: Routledge.

Goldstein, Jeffrey (1999), 'Emergence as a Construct: History and Issues’, Emergence, 1(1): 49-72.

Grossman, Sanford and Oliver D. Hart (1986), 'The Costs and Benefits of Ownership: A Theory of Vertical and Lateral Integration', Journal of Political Economy, 94(2): 691-719.

Hager, Mark M. (1989), 'Bodies Politic: The Progressive History of Organizational "Real Entity” Theory', University of Pittsburgh Law Review, 50(3): 575-654.

Hansmann, Henry and Reinier Kraakman (2000), 'The Essential Role of Organizational Law', Yale Law Journal, 110(3): 387-440.

Hansmann, Henry, Kraakman, Reinier and Richard Squire (2005), 'The New Business Entities in Evolutionary Perspective', University of Illinois Law Review, 2005(1): 514.

Hansmann, Henry, Kraakman, Reinier and Richard Squire (2006), 'Law and the Rise of the Firm', Harvard Law Review, 119(5): 1333-1403.

Harré, Rom and Edward H. Madden (1975), Causal Powers: A Theory of Natural Necessity, Oxford: Basil Blackwell.

Harris, Ron (2006), 'The Transplantation of the Legal Discourse on Corporate Personality Theories: From German Codification to British Political Pluralism and American Big Business', Washington and Lee Law Review, 63(4): 1421-1478.

Hart, Oliver D. (1989), 'An Economist's Perspective on the Theory of the Firm', Columbia Law Review, 89(7): 1757-1774. 
Hart, Oliver D. (1995), Firms, Contracts and Financial Structure, New York: Oxford University Press.

Hart, Oliver D. and John Moore (1990), 'Property Rights and the Nature of the Firm', Journal of Political Economy, 98(6): 1119-1158.

Hessen, Robert (1979), 'A New Concept of Corporations: A Contractual and Private Property Model', Hastings Law Journal, 30(5): 1327-1350.

Hodgson, Geoffrey M. (2002), 'The Legal Nature of the Firm and the Myth of the FirmMarket Hybrid', International Journal of the Economics of Business, 9(1): 36-60.

Hodgson, Geoffrey M. (2003), 'The Hidden Persuaders: Institutions and Individuals in Economic Theory', Cambridge Journal of Economics, 27(2): 159-175.

Hodgson, Geoffrey M. (2004), On the Evolution of Institutional Economics: Agency, Structure and Darwinism in American Institutionalism, London and New York: Routledge.

Hodgson, Geoffrey M. and Thorbjørn Knudsen (2004), 'The Firm as an Interactor: Firms as Vehicles for Habits and Routines', Journal of Evolutionary Economics, 14(2): 281307.

Horwitz, Morton J. (1992), The Transformation of American Law, 1870-1960: The Crisis of Legal Orthodoxy, New York: Oxford University Press.

Humphreys, Paul (1997), 'Emergence, Not Supervenience', Philosophy of Science, 64(S): S337-S345.

Iacobucci, Edward M. and George G. Triantis (2007), 'Economic and Legal Boundaries of the Firm', Virginia Law Review, 93(3): 515-570.

Iwai, Katsuhito (1999), 'Persons, Things and Corporations: The Corporate Personality Controversy and Comparative Corporate Governance', American Journal of Corporation Law, 47(4): 583-632.

Jensen, Michael C. and William H. Meckling (1976), 'Theory of the Firm: Managerial Behavior, Agency Costs and Capital Structure', Journal of Financial Economics, 3(4): 305-360.

Jhering, Rudolf (1852) Der Geist des römischen Rechts, Leipzig: Auflage.

Khalil, Elias L. (1997), 'Is the Firm an Individual?', Cambridge Journal of Economics, 21(4): 519-544. 
Kim, Jaegwon (2006), 'Emergence: Core Ideas and Issues', Synthese, 151(3): 547-559.

Klein, William A. and John C. Coffee (2002), Business Organization and Finance: Legal and Economic Principles, $8^{\text {th }}$ edition, New York: Foundation Press.

Lamoreaux, Naomi R. (1998), 'Partnerships, Corporations and the Theory of the Firm', American Economic Review, 88(2): 66-71.

Laski, Harold J. (1916), 'The Personality of Associations', Harvard Law Review, 29(4): 404-426.

Lawson, Tony (1997), Economics and Reality, London and New York: Routledge.

Leibniz, Gottfried W. (1902 [1687]), Correspondence with Arnauld, in Thomas J. McCormack (ed.), Leibniz: Basic Writings, La Salle, IL: Open Court.

Lowe, Jonathan E. (2003), 'Identity, Individuality and Unity', Philosophy, 78(3): 321-336.

Machen, Arthur W. (1911), 'Corporate Personality’, Harvard Law Review, 24(4): 253-267.

Mahoney, Paul G. (2000), 'Contract or Concession? An Essay on the History of Corporate Law', Georgia Law Review, 34(2): 873-893.

Maitland, Frederick W. (1900), 'The Corporation Sole', Law Quarterly Review, 16(4): 335354.

Maitland, Frederick W. (1905), 'Moral Personality and Legal Personality', Journal of the Society of Comparative Legislation, 6(2): 192-200.

Mäki, Uskali (2001), 'The Way the World Works (www): Towards an Ontology of Theory Choice', in Uskali Mäki (ed.), The Economic World View: Studies in the Ontology of Economics, Cambridge: Cambridge University Press.

Mark, Gregory A. (1987), 'The Personification of the Business Corporation in American Law', University of Chicago Law Review, 54(4): 1441-1483.

Masten, Scott E. (1988), 'A Legal Basis for the Firm', Journal of Law, Economics and Organization, 4(1): 181-198.

Millon, David (1990), ‘Theories of the Corporation', Duke Law Journal, 1990(2): 201-262.

Molnar, George (2003), Powers: A Study in Metaphysics, Oxford: Oxford University Press.

Moore, John (1992), 'The Firm as a Collection of Assets', European Economic Review, 36(2-3): 493-507. 
Naffine, Ngaire (2003), 'Who are Law's Persons? From Cheshire Cats to Responsible Subjects', Modern Law Review, 66(3): 346-367.

Nelson, Richard R. and Sidney G. Winter (1982), An Evolutionary Theory of Economic Change, Cambridge, MA: Harvard University Press.

Orts, Eric W. (1998), 'Shirking and Sharking: A Legal Theory of the Firm', Yale Law and Policy Review, 16(2): 254-329.

Orts, Eric W. (2007), Rethinking the Firm: Theories of the Business Enterprise, unpublished book manuscript (forthcoming, Oxford University Press).

Penrose, Edith T. (1959), The Theory of the Growth of the Firm, Oxford: Basil Blackwell.

Pettit, Philip (2002), 'Collective Persons and Powers', Legal Theory, 8(4): 443-470.

Phillips, Michael J. (1994), 'Reappraising the Real Entity Theory of the Corporation', Florida State University Law Review, 21(4): 1061-1123.

Plato, Sophist, in Edith Hamilton and Huntington Cairns (1980) (eds), Plato: The Collected Dialogues, $10^{\text {th }}$ edition, Princeton, NJ: Princeton University Press.

Quine, Willard V.O. (1969), Ontological Relativity and Other Essays, New York: Columbia University Press.

Radin, Max (1932), ‘The Endless Problem of Corporate Personality', Columbia Law Review, 32(4): 643-667.

Ribstein, Larry E. (2006), 'Should History Lock In Lock-In?', Tulsa Law Review, 41(3): 523-539.

Rowley, Scott (1931), 'The Individuality of Business Associations', Virginia Law Review, 17(6): 557-569.

Savigny, Friedrich C. (1841), System des heutigen Römischen Rechts, vol.2, Berlin: Veit.

Searle, John R. (2005), 'What Is an Institution?', Journal of Institutional Economics, 1(1): $1-22$.

Simon, Herbert A. (1991), 'Organizations and Markets', Journal of Economic Perspectives, 5(2): 25-44.

Singleton, W.E. (1912), 'Entities and Real and Artificial Persons', Journal of the Society of Comparative Legislation, 12(2): 291-298. 
Stauss, James H. (1944), 'The Entrepreneur: The Firm', Journal of Political Economy, 52(2): 112-127.

Stout, Lynn A. (2005), 'The Nature of Corporations', University of Illinois Law Review, 2005(1): 253-267.

Thomasson, Amie L. (2003), 'Realism and Human Kinds', Philosophy and Phenomenological Research, 67(3): 580-609.

Vanberg, Victor J. (1992), 'Organizations as Constitutional Systems', Constitutional Political Economy, 3(3): 223-253.

Vinogradoff, Paul (1924), 'Juridical Persons', Columbia Law Review, 24(6): 594-604.

Weissman, David (2000), A Social Ontology, New Haven, CT: Yale University Press.

Williamson, Oliver E. (1975), Markets and Hierarchies: Analysis and Antitrust Implications, New York: Free Press.

Wimsatt, William C. (1997), 'Aggregativity: Reductive Heuristics for Finding Emergence', Philosophy of Science, 54(S): S372-S384.

Winter, Sidney G. (1988), 'On Coase, Competence and the Corporation', Journal of Law, Economics and Organization, 4(1): 163-180.

Wormser, I. Maurice (1912), 'Piercing the Veil of Corporate Entity', Columbia Law Review, 12(6): 496-518.

Zingales, Luigi (2000), 'In Search of New Foundations', Journal of Finance, 55(4): 16231653. 